\title{
Germ Line Chimeras from Female ES Cells
}

\author{
A. K. Voss, ${ }^{1}$ T. Thomas, And P. Gruss \\ Department of Molecular Cell Biology, Max-Planck Institute of Biophysical Chemistry, Goettingen, Germany
}

\begin{abstract}
Murine embryonic stem cells (ES cells) are pluripotent cells that can contribute to all tissues of developing mice including the germ line when aggregated with 8-cell-stage embryos or injected into the blastocoel cavity of murine blastocysts. As well as for in vitro studies, they are used to introduce mutations into the murine genome, thereby producing new mutant mouse lines. All ES cell lines so far described that contribute to the germ line have been male. However, for many studies female ES cell lines may be essential. Female ES cells may be particularly useful for mutating genes located on the $X$ chromosome which would otherwise be hemizygously lethal in males. We show here that female ES cells are able to form germ line chimeras and to sex convert a male host embryo. $\odot 1997$ Academic Press
\end{abstract}

\section{INTRODUCTION}

Murine embryonic stem cells (ES cells) [1, 2] are widely used as vehicles to introduce null or subtle mutations targeted into specific genes of the mouse genome and to produce mutant mouse strains to analyze the loss of function phenotype in homozygous animals [3, 4, for reviews see 5, 6]. All ES cell lines tested for germ line transmission and currently available are male lines [7-15]. Male ES cell lines have the advantage that normally the resulting germ line chimeras are males and can father a large number of offspring in a short period of time. However, male cells are hemizygous for most gene loci on the $X$ chromosome [16]. Female germ line chimeras may be preferable for gene targeting experiments on the $\mathrm{X}$ chromosome, if a mutation is lethal in hemizygous animals or cells. To establish animal models for $X$ chromosome-linked human diseases which are lethal for carrier males may in some cases be impossible with male ES cell lines. We report here the generation of germ line chimeras from female

\footnotetext{
${ }^{1}$ To whom correspondence and reprint requests should be addressed at Department of Molecular Cell Biology, Max-Planck Institute of Biophysical Chemistry, Am Fassberg 11, 37077 Goettingen, Germany. Telephone: 49551 2011507. Fax: 49551 2011504. E-mail: avoss@gwdg.de.
}

ES cells, compare their efficiency to that of male ES cells generated under the same conditions, and demonstrate that there is no barrier to the production of genetically normal female germ line chimeras.

\section{MATERIALS AND METHODS}

Animals. Mice were kept at $21^{\circ} \mathrm{C}, 55 \%$ relative humidity, on a light 5:00 h to 19:00 h/dark 19:00 h to 5:00 h cycle, and fed water and breeding quality feed ad libitum. Adult female mice were superovulated and used as embryo donors as described previously [17]. Pseudopregnant recipient females were naturally mated to vasectomized males as described previously [17].

Embryo recovery. Late blastocysts were recovered from superovulated, mated, and plugged females at Day 3.75 of gestation in the evening (E3.75, with 12:00 $\mathrm{h}$ noon of the day of the vaginal plug being E 0.5) as described by Hogan et al. [17].

Establishment of new ES cell lines. ES cell lines were established essentially as described by Nagy et al. [9]. In brief, cleavage inactivated feeder cell monolayers of either SNL cells [8] or primary murine embryonic fibroblasts were prepared on 1.5-cm wells of 4-well plates (Nunc) as described previously [18]. Blastocysts were plated in ES cell medium (DMEM, $4500 \mathrm{mg} /$ liter glucose, Gibco; $10^{-4} \mathrm{M} \beta$ mercaptoethanol, Sigma; $1 \times$ nonessential amino acids, Gibco; $1 \times \mathrm{L}$ glutamine, Gibco; $1 \times$ sodium pyruvate, Gibco; $20 \%$ fetal bovine serum, tested for ES cell culture, Boehringer; $1000 \mathrm{IU} / \mathrm{ml} \mathrm{mLIF}, \mathrm{Gibco}$ ). They were incubated for approximately 5 days without medium change. Blastocysts hatched from zonae pellucidae and attached to the feeder cell layer. Trophoblasts flattened and inner cell masses grew out.

After 5 to 6 days of culture, inner cell masses were picked, enzymatically and mechanically dissociated, and replated. Within 6 to 9 days colonies grew. Colonies with ES cell-like morphology were picked, dissociated, and plated. After 4 to 6 days many colonies per well were visible and passaged to $3.5-\mathrm{cm}$ dishes. We counted passage numbers of ES cell lines from the first passage to a $3.5-\mathrm{cm}$ petri dish as passage 1 .

Sex determination. To test new ES cell lines for the presence or absence of a $Y$ chromosome we isolated DNA from the cells as described previously [19] and amplified 279 bp of the sex-determining region of the $\mathrm{Y}$ chromosome (SRY) by polymerase chain reaction using two oligonucleotides, as described previously [20] (forward primer, 5'-GTCAAGCGCCCCATGAATGCA-3'; reverse primer, 5'GTTTTGTTGAGGCAACTGCA-3' ), under the following PCR conditions: $50 \mathrm{mM} \mathrm{KCl}, 10 \mathrm{mM}$ Tris- $\mathrm{HCl}, 2 \mathrm{mM} \mathrm{MgCl}_{2}, 0.1 \%$ Triton $\mathrm{X}$ 100, $0.2 \mathrm{mM}$ dNTPs, for (1) denaturing: $94^{\circ} \mathrm{C}, 5 \mathrm{~min}$; (2) denaturing: $94^{\circ} \mathrm{C}, 1 \mathrm{~min}$; (3) annealing: $64^{\circ} \mathrm{C}, 1 \mathrm{~min}$; (4) extension: $72^{\circ} \mathrm{C}, 1 \mathrm{~min}$, 35 cycles of (2) to (4) and (5) final extension: $72^{\circ} \mathrm{C}, 10 \mathrm{~min} . \mathrm{PCR}$ products were separated on a $2 \%$ agarose gel and visualized with ethidium bromide.

The same PCR technique was used to determine if contribution of cells from a male host embryo was detectable in female aggregation chimeras. These PCR results were verified by Southern analysis as described previously [21] using a Y-repeat probe [22]. 
TABLE 1

Efficiency of ES Cell Line Generation

\begin{tabular}{lccc}
\hline $\begin{array}{l}\text { Mouse } \\
\text { strain }\end{array}$ & $\begin{array}{c}\text { Embryos } \\
\text { used }\end{array}$ & $\begin{array}{c}\text { ES cell } \\
\text { lines } \\
\text { established }\end{array}$ & $\begin{array}{c}\text { Embryos } \\
\text { used/lines } \\
\text { established }\end{array}$ \\
\hline $129 / \mathrm{J}$ & 26 & 1 & 26 \\
$129 / \mathrm{Sv}$ & 118 & 16 & 7.3 \\
Splotch $^{2 \mathrm{H} \text { a }}$ & 92 & 20 & 4.6 \\
Total & 237 & 37 & 6.4 \\
\hline
\end{tabular}

${ }^{a}$ Splotch ${ }^{2 \mathrm{H}}$ embryos are derived from splotch ${ }^{2 \mathrm{H}}$ mice crossed back to $\mathrm{C} 57 \mathrm{BL} / 6$ for five generations.

Metaphase chromosome spreads. Metaphase chromosome spreads of ES cells were prepared as described by Robertson [23]. Photographic slides were taken of metaphase chromosome spreads at $630 \times$ magnification and projected to a screen where chromosomes were counted.

Production of chimeras. Chimeras were produced by aggregation with 8-cell-stage embryos as described by Nagy [24]. To test chimeras for germ line transmission they were mated to males or females of the strain of the host embryos.

Statistics. Means of pregnancy rates and litter sizes are given \pm standard deviation. Means that differ with nonoverlapping standard deviations are significantly different with $P \leqslant 0.05$.

\section{RESULTS}

New ES cell lines were established from 129/] , 129/ Sv, and splotch ${ }^{2 \mathrm{H}}$ mutant mice, a Pax3 mutant mouse strain. On average, 1 ES cell line was generated from 6.4 embryos. The efficiency ranged from 1 ES cell line from 26 embryos (129/J ) to 1 ES cell line from 4.6 embryos (splotch ${ }^{2 \mathrm{H}}$; Table 1).

ES cell lines generated from 129/Sv mice were analyzed further to predict their usefulness for genetransfer and developmental studies. Five of 10 lines were positive for $Y$ chromosome-specific sequences as analyzed by SRY-PCR. At passage 6, 10 metaphase chromosome spreads each were prepared from 13 ES cell lines and chromosomes were counted. Ninety percent of the metaphase spreads of all lines exhibited the nominal number of 40 chromosomes. At passages 10 and 12,5 of 6 lines tested (MPI-I, -II , -III, -V, and -VI) were euploid. One line (MPI-IV) was aneuploid.

The developmental potential of 4 male and 2 female ES cell lines (MPI-I to -VI) was tested by aggregating small cell clumps of these lines at passages 6 to 7 with zonaless 8-cell-stage embryos. Thirty-six to $107 \mathrm{em}$ bryos were aggregated with cells from each line and transferred to recipients, as indicated in Table 2. Chimeras developed to term and were delivered naturally or by cesarian section and then transferred to foster animals. Four lines generated germ line chimeras with an efficiency of 1 germ line chimera produced from 12 to 46 aggregated and transferred embryos (Table 2).
One male and 1 female line did not produce live newborns (Table 2).

Contribution of ES cells to tissues of chimeric animals was assessed by coat color (contribution to pigmented cells) and germ line transmission (contribution to gametogenesis). F our of the 6 lines tested produced adult chimeras with $100 \%$ ES cell contribution to pigmented cells as judged by coat color (Table 3). GPI analysis done on newborn and adult chimeras of lines MPI-I and MPI-II revealed $100 \%$ ES cell-derived animals. Twelve of 14 chimeras were germ line chimeras, and 10 of them were $100 \%$ germ line chimeras. All 7 chimeras derived from male ES cell lines were male, and 6 of 7 chimeras derived from female ES cells were female, evidencing contribution of ES cells to the gonads. PCR amplification of part of the SRY gene revealed that 1 of the 5 female germ line chimeras was derived from an aggregation of the female ES cell line with a male host embryo. The presence of $Y$-repeat sequences was al so readily visi ble by Southern analysis (Fig. 1). This female chimera was anatomically normal. Histological examination of the gonads revealed only ovarian tissue. The sex-converted male host embryo contributed sufficient material to allow PCR amplification of its SRY gene and Southern hybridization of its $Y$-repeats.

All 4 lines that produced chimeras also resulted in germ line chimeras which transmitted the ES cell genome to $100 \%$ of their offspring (Table 3). All male chimeras exhibited normal fertility. A minimum of 50 pups was bred from male chimeras and evaluated for transmission of the wild-type agouti gene (ES cell derived). Four of 5 female chimeras generated from female ES cell lines transmitted the ES cell genome to $100 \%$ of their offspring (Table 3), but produced litters of very small sizes. The normal litter size of $129 / \mathrm{Sv}$ mice in our breeding colony is $6.3 \pm 2.4$, whereas these female chimeras had litters of $1.5 \pm 0.5$ pups. Therefore, only few pups of female germ line chimeras have been born so far $(7,8,4,9$, and 5, from 5 germ line chimeras, respectively).

\section{DISCUSSION}

We have established male and female ES cell lines which form germ line chimeras with high efficiency upon aggregation with 8-cell-stage embryos. These ES cell lines contribute $100 \%$ to the germ line and to coat color of 10 of 14 chimeras. Comparable results have been communicated only by Nagy and co-workers, who aggregated ES cells with tetraploid embryos and recovered mice with $100 \%$ ES cell contribution to coat color and gametogenesis of 3 of 3 germ line chimeras [9]. Extensive to minor ES cell contribution to coat color or coat color mosaicism has been reported previously [1], 25]. Parental ES cell contribution to gametogenesis 
TABLE 2

Efficiency of Germ Line Chimera Production

\begin{tabular}{llcccc}
\hline $\begin{array}{l}\text { ES cell } \\
\text { line }\end{array}$ & Sex & $\begin{array}{c}\text { Embryos aggregated } \\
\text { and transferred }\end{array}$ & $\begin{array}{c}\text { Live adult } \\
\text { chimeras }\end{array}$ & $\begin{array}{c}\text { Germ line } \\
\text { chimeras }\end{array}$ & $\begin{array}{c}\text { Embryos/germ } \\
\text { line chimera }\end{array}$ \\
\hline MPI-I & Male & 52 & 2 & 2 & 26 \\
MPI-II & Male & 36 & 3 & 3 & 12 \\
MPI-III & Male & 94 & 0 & - & - \\
MPI-IV & Female & 61 & 0 & 2 & 46 \\
MPI-V & Male & 91 & 2 & 5 & 21 \\
MPI-VI & Female & $107^{+}$ & 7 & - \\
\hline
\end{tabular}

a Number of embryos includes embryo transfers resulting in pregnancies only (Pregnancy rate $=80 \pm 16 \%$ ).

${ }^{b}$ Grown on gelatin-coated plastic instead of feeder cells. ${ }^{+}$ES cells aggregated with CD1 embryos; all other ES cells were aggregated with C57BL/6 embryos.

was described previously as between 2 and $80 \%$ [26, 27]. Others reported one $100 \%$ germ line chimera in 20 germ line chimeras generated or one $100 \%$ germ line chimera in 5 germ line chimeras generated [11, 25].

We observed a high number of chimeras with $100 \%$ ES cell contribution to the coat color and did not find the stripes observed typically in chimeric mice generated by blastocyst injection. In cases of lower ES cell contribution we rather saw a "salt and pepper" type mixing of host cells and ES cells. We attribute this difference in contribution to the pigmented cell population to the difference in technique used to produce the chimeras. It seems that ES cells aggregated with 8cell-stage embryos can easily take over the whole embryo or, in the case of lower contribution, mix in completely with the host cells, whereas ES cells injected into the blastocoel cavity in many cases may not have time to mix with the inner cell mass cells before further differentiation takes place.

TABLE 3

ES Cell Contribution to Pigment Cells and Gametogenesis

\begin{tabular}{cccc}
\hline $\begin{array}{c}\text { ES cell } \\
\text { line }\end{array}$ & $\begin{array}{c}\text { Adult } \\
\text { chimeras }\end{array}$ & $\begin{array}{c}\text { Coat color } \\
\text { contribution of } \\
\text { ES cells }\end{array}$ & $\begin{array}{c}\text { ES cell } \\
\text { contribution to } \\
\text { gametes }\end{array}$ \\
\hline MPI-I & 1 & 100 & 100 \\
MPI-II & 2 & 100 & 100 \\
& 1 & 100 & 100 \\
MPI-III & 2 & 100 & 100 \\
MPIIIV & 3 & 100 & 100 \\
MPI-V & 0 & - & - \\
MPI-VI & 1 & - & - \\
& 2 & 100 & 100 \\
& 1 & 95 & 90 \\
& 2 & 100 & 100 \\
& 3 & 100 & 100 \\
& 4 & 100 & 100 \\
& 5 & 100 & 100 \\
& 6 & 95 & 09 \\
& 7 & 50 & 0 \\
\hline
\end{tabular}

\section{Female ES Cell Lines}

Several ES cell lines established from preimplantation embryos have been previously reported $[1,2,7,28]$. These ES cell lines have been widely used to introduce targeted mutations into genes of the murine genome. All ES cell lines used in this context have been male. For most applications male ES cell lines are sufficient
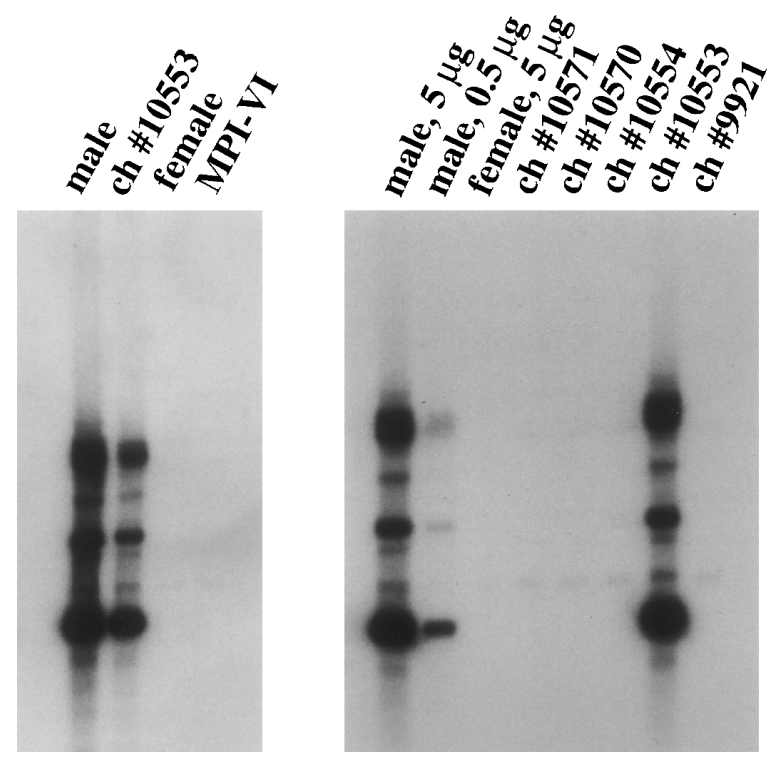

FIG. 1. Southern analysis of genomic DNA cut with $\mathrm{Ncol}$ of control male mice (male), control female mice (female), female ES cells (MPI-VI), and female chimeras (ch \#Animal No.). $10 \mu \mathrm{g}$ of DNA was loaded per lane unless indicated otherwise. Southern blot was hybridized with a $Y$ chromosome-specific probe for $Y$-repeats. (Left) The absence of $Y$-repeats in the female ES cell line MPI-VI and in female control DNA and the presence of $Y$-repeats in male control DNA and the female germ line chimera $\# 10553$, which was generated by aggregating MPI-VI cells with a presumably male host embryo (10 $\mu \mathrm{g}$ of DNA per lane each). (Right) The absence of $Y$-repeats in female control DNA (5 $\mu \mathrm{g}$ per lane) and in chimeras \#9921, 10554, 10570, and 10571 (10 $\mu \mathrm{g}$ per lane, each) and the presence of $\mathrm{Y}$-repeats in male DNA (5 $\mu \mathrm{g}$ and $0.5 \mu \mathrm{g}$ per lane) and in the female chimera \#10553 (10 $\mu \mathrm{g})$. 
and preferable, as the resulting male chimeras can father a large number of offspring in a short period of time. For the same reason, male ES cell lines are also preferable for targeting genes on the $X$ chromosome that do not lead to lethal mutant phenotypes, for example the 5- $\mathrm{HT}_{2 \mathrm{c}}$ serotonin receptor [29]. H owever, lethal mutations of genes on the $X$ chromosome might be expected to impair the production of male germ line chimeras seriously or may already be lethal in ES cells. In these cases it may be preferable to use a female ES cell line.

Female ES cell lines have been produced [11, 30] and used for studies in vitro[30] and for chimera production [11]. However, germ line chimera production from female ES cell lines has not been reported. Here, we describe female germ line chimeras resulting from female ES cells.

All chimeras derived from male ES cell lines were male and six of seven chimeras derived from female ES cell lines were female. The only male chimera that was derived from female ES cells exhibited the lowest ES cell contribution to the pigmented population ( $40 \%$ ES cell contribution to coat color) and was, as expected, not a germ line chimera. In this case the female ES cells may have failed to convert the sex of their male host simply because there were more host cells than ES cells present in the developing gonad. Distortion of the normal sex ratio indicates that ES cell colonized the developing gonads efficiently and overrode the sexdetermining signals of host embryos.

Four of five female germ line chimeras described here transmitted the ES cell genome to $100 \%$ of their offspring and one of five transmitted it to $89 \%$ of her offspring, but their litter size was very small, whereas male chimeras exhibited normal fertility. During embryonic development an approximately 10-fold excess of oogonia is produced during the mitotic phase of oogenesis which later, before birth and between birth and puberty, is reduced by atresia [31]. If ES cells had a reduced proliferative potential compared with blastomeres of normal embryos, this could interfere with the production of large numbers of oogonia so that a much lower number of oocytes would be present in the ovaries at the beginning of the fertile phase. As the number of ocytes ovulated appears to be linked to the number of ocytes remaining in the ovaries, a lower number of ovulated oocytes may result in female chimeras. In contrast, a lower number of spermatozoa ejaculated by a male chimera would not become apparent, as the spermatozoa would still outnumber the oocytes ovulated by a wild-type female manifold. A reduced proliferative potential of ES cells compared with blastomeres of normal embryos also seems likely, because chimeras which are $100 \% \mathrm{ES}$ cell derived are often smaller than wild-type 129/Sv. Other ES cell lines would be needed to determine whether the observed difference in fertil- ity between male and female ES cells is a general problem of female ES cell lines.

This report of germ line chimera production from female ES cells proves that there are no barriers in principle for female ES cells to colonize the germ line of a host embryo. Furthermore, it suggests that the complicated mechanism of $X$ chromosome inactivation occurs normally $[32,33]$. Female embryos which do not undergo $X$ chromosome inactivation exhibit abnormal development as shown in Searle's $X$ autosome translocation at least for some X-linked genes [34]. Moreover, we have shown that female ES cells can convert the sex of male host embryos. Sex conversion of a male embryo by female ES cells has not been shown previously, but was to be expected, if one assumed that female ES cells exhibited the same developmental potential as female preimplantation embryos. Seventeen to $25 \%$ of $X X-X Y$ aggregation chimeras of preimplantation embryos developed to phenotypically normal females, evidencing the capability of female embryos to convert the sex of male embryos [for review see 35, 36].

In summary we have shown that female ES cells can form germ line chimeras and can convert the sex of a male host embryo to a normal female germ line chimera.

We gratefully appreciate the excellent technical help of M. Stäger, R. Emeny, V. Diaz Salamanca, S. Meyer, and G. Weinrich. We thank M. Torres for critical discussion. This work was supported by Deutsche Forschungs Gemeinschaft (fellowship to A.K.V.), by the European Molecular Biology Organization (fellowship to T.T.), and by Amgen Inc., Thousand Oaks, CA.

\section{REFERENCES}

1. Evans, M. J ., and Kaufman, M. H. (1981) Nature 292, 154- 156.

2. Martin, G. R. (1981) Proc. Natl. Acad. Sci. USA 78, 7634- 7638.

3. Mansour, S. L., Thomas, K. R., and Capecchi, M. R. (1988) Nature 336, 348- 352.

4. Rubinstein, M., J apón, M. A., and Low, M.J. (1993) Nucleic Acids Res. 21, 2613- 2617.

5. Capecchi, M. R. (1989) Science 244, 1288- 1292.

6. Ramirez-Solis, R., Davis, A. C., and Bradley, A. (1993) Methods Enzymol. 225, 855- 878.

7. Doetschman, T.C., Eistetter, H., Katz, M., Schmidt, W., and Kemler, R. (1985) J . Embryol. Exp. Morphol. 87, 27- 45.

8. McMahon, A. P., and Bradley, A. (1990) Cell 62, 1073- 1085.

9. Nagy, A., Rossant, J., Nagy, R., Abramow-Newerly, W., and Roder, J . C. (1993) Proc. Natl. Acad. Sci. USA 90, 8424-8428.

10. Handyside, A. H., O'Neil, G. T., J ones, M., and Hooper, M. (1989) Roux's Arch. Dev. Biol. 198, 48- 55.

11. Nichols, J., Evans, E. P., and Smith, A. G. (1990) Development 110, 1341- 1348.

12. Soriano, P., Montgomery, C., Geske, R., and Bradley, A. (1991) Cell 64, 693-702.

13. Robertson, E.J ., Bradley, A., Kuehn, M., and Evans, M. (1986) Nature 323, 445- 448.

14. Bradley, A., Evans, M., Kaufman, M.H., and Robertson, E. (1984) Nature 309, 255- 256. 
15. Saga, Y., Yagi, T., I kawa, Y., Sakakura, T., and Aizawa, S. (1992) Genes Dev. 6, 1821- 1831.

16. Alberts, B., Bray, D., Lewis, J ., Raff, M., Roberts, K., and Watson, J . D. (1989) Molecular Biology of the Cell, Garland, New York.

17. Hogan, B. L. M., Constantini, F., and Lacy, E. (1986) Manipulating the Mouse Embryo: A Laboratory Manual, Cold Spring Harbor Laboratory, Cold Spring Harbor, NY.

18. Wurst, W., and J oyner, A. L. (1993) in Gene Targeting. A Practical Approach (J oyner, A. L., Ed.), pp. 33-61, IRL Press, Oxford.

19. Sambroock, J ., Fritsch, E. F., and Maniatis, T. (1989) Molecular Cloning. A Laboratory Manual, second ed., Cold Spring Harbor Laboratory, Cold Spring Harbor, NY.

20. Bächner, D., Manca, A., Steinbach, P., Wöhrle, D., J ust, W., Vogel, W., Hameister, H., and Poustka, A. (1993) Hum. Mol. Genet. 2, 2043- 2050.

21. Church, G. M., and Gilbert, W. (1984) Proc. Natl. Acad. Sci. USA 81, 1991- 1995.

22. Nishioka, A. Y. (1988) Teratology 38, 181- 185.

23. Robertson, E.J. (1987) in Teratocarcinomas and Embryonic Stem Cells. A Practical Approach (Robertson, E.J., Ed.), pp. 71-112, IRL Press, Oxford.

24. Nagy, A., and Rossant, J . (1993) in Gene Targeting. A Practical Approach (J oyner, A. L., Ed.), pp. 14-178, IRL Press, Oxford.
25. Brown, D. G., Willington, M. A., Findlay, I., and Muggleton-Harris, A. L. (1992) In Vitro Cell. Dev. Biol. 28A, 773-778.

26. Suda, Y., Suzuki, M., Ikawa, Y., and Aizawa, S. (1987) J . Cell. Physiol. 133, 197- 201.

27. Gossler, A., Doetschman, T., Korn, R., Serfling, E., and Kemler, R. (1986) Proc. Natl. Acad. Sci. USA 83, 9065- 9069.

28. Axelrod, H. R. (1984) Dev. Biology 101, 225- 228.

29. Tecott, L. H., Sun, L. M., Akana, S. F., Strack, A. M., Lowenstein, D. H., Dallman, M. F., and J ulius, D. (1995) Nature 374, 542- 546.

30. Tada, T., Tada, M., and Takagi, N. (1993) Devel opment 119, 813821.

31. Peters, H., and McNatty, K. P. (1980) The Ovary, Univ. of California Press, Berkeley.

32. Tam, P.P. L., Zhou, S. X., and Tan, S.-S. (1994) Development 120, 2925- 2932.

33. Tan, S.-S., Williams, E.A., and Tam, P.P. L. (1993) Nature Genet. 3, 170- 174.

34. Takagi, N., and Abe, K. (1990) Development 109, 189- 201.

35. McLaren, A. (1984) in Chimeras in Developmental Biology (Le Douarin, N., and McLaren, A., Eds.), pp. 381-399, Academic Press, London.

36. MCLaren, A. (1984) in Chimeras in Developmental Biology (Le Douarin, N., and McLaren, A., Eds.), pp. 111-129, Academic Press, London. 